2010

\title{
Cost and Fee Allocation in Civil Procedure
}

James Maxeiner

University of Baltimore School of Law, jmaxeiner@ubalt.edu

Follow this and additional works at: http://scholarworks.law.ubalt.edu/all_fac

Part of the Courts Commons, and the Legal Profession Commons

\section{Recommended Citation}

Cost and Fee Allocation in Civil Procedure, 58 Am. J. Comp. L. 195 (2010)

This Article is brought to you for free and open access by the Faculty Scholarship at ScholarWorks@University of Baltimore School of Law. It has been accepted for inclusion in All Faculty Scholarship by an authorized administrator of ScholarWorks@University of Baltimore School of Law. For more information, please contact snolan@ubalt.edu. 


\section{JAMES R. MAXEINER*}

\section{Cost and Fee Allocation in Civil Procedure $\dagger$}

Court costs in American civil procedure are allocated to the loser ("loser pays") as elsewhere in the civilized world. As Theodor Sedgwick, America's first expert on damages opined, it is matter of inherent justice that the party found in the wrong should indemnify the party in the right for the expenses of litigation. Yet attorneys' fees are not allocated this way in the United States: they are allowed to fall on the party that incurs them (the "American rule," better, the American practice). According to Albert Ehrenzweig, Austrian judge, émigré and then prominent American law professor, the American practice is "a festering cancer in the body of our law." This Article surveys American cost and fee allocation practices. The author hopes that the Article will serve as a prolegomenon from an American perspective for moreencompassing comparative studies, including eventually of empirical studies. Preparing this Article has led the author to believe that the impact of fee allocation systems has been underappreciated in evaluation of how well nations in fact deliver civil justice.

There seem to be strong a priori reasons for believing that a rule which made the loser bear a greater part of his adversary's expenses of suit would encourage compromises and diminish litigation, but confident conclusions about the matter must await further research. A preliminary survey and comparison of the practices which obtain in all the principal foreign countries in this respect might shed some light upon the question.

Charles T. McCormick, Attorneys' Fees and Other Expenses of Litigation as an Element of Damages, 15 Minn. L. Rev. 619, 642 (1931).

* (C) 2010, James R. Maxeiner, J.D., Cornell; LL.M., Georgetown; Ph.D. in Law, Ludwig Maximilian University (Munich, Germany). Associate Professor of Law and Associate Director, Center for International and Comparative Law, University of Baltimore School of Law. I would like to thank Professor John Leubsdorf for his helpful comments on an earlier draft of this Article.

$\dagger$ DOI 10.5131/ajcl.2009.0027. 


\section{Prologue and Introduction}

In 1931 Professor Charles T. McCormick, a leading expert of the day on damages in U.S.-American law, wished for the study that the International Academy of Comparative Law is now conducting for the 18th World Congress in 2010 in Washington DC. Had only the Academy fulfilled that wish and addressed this topic at its 1st World Congress in 1937, just possibly the United States might have a system of civil procedure quite different from what it does have today.

Had there been better knowledge in the United States of the rules applied elsewhere, just possibly the Federal Rules of Civil Procedure of 1938 might have rejected the American practice that each party bears its own attorneys' fees and might have substituted in its stead what we discuss here as the "loser pays" rule. The World Congress did not, however, address this theme and December twentieth of that very year the U.S. Supreme Court reported the Federal Rules of Civil Procedure to the U.S. Congress, which permitted them to become law in 1938.

Within the Federal Rules lay an innovation called discovery, the full effect of which in 1938 was not dreamt of, but which later, when combined with the practice of no-indemnity for attorneys' fees and with a change in lawyers' billing, seriously compromised the American system of civil procedure as a practical means for justly deciding fixed claims of ordinary size. Most states imitated the federal rules in most respects including discovery. Today discovery accounts for the lion's share of litigation expenses. Lawyers for the parties control the amount of discovery. That means that they determine total attorneys' fees. The practice of no-indemnity allows them to render the victories of their adversaries pyrrhic and the claims of their adversaries' clients worthless. ${ }^{1}$

This report describes cost and fee allocation under the civil procedure of the federal courts of the United States and of the State of New York. It does not address the cost and fee allocation systems of the other forty-nine states of the United States other than in occasional generalities. Each state has its own unique rules. While these rules vary in detail, most parallel the federal or New York systems. The principal exception is that of Alaska, which is a variation of loser pays. $^{2}$

1. For a look at how this works in real life, see Jonathan B. WiLson, OUT of Balance: Prescriptions for Reforming the American Litigation System 41-59 (2005). For a look at similar issues in England with reference to German and American practices, see Adrian Zuckerman, Lord Justice Jackson's Review of Civil Litigation Costs-Preliminary Report (2009), 28 Crv. Just.Q. 435 (2009).

2. See Walter Olson \& David Bernstein, Loser Pays: Where Next?, 42 AM. U. L. REv. 1571, 1180-1186 (1996). 


\section{The Basic Rules: Who Pays?}

The basic rules of allocation are different for court costs and for attorneys' fees. For court costs, the losing party pays all of the prevailing party's costs; only exceptionally is there a reduction. FED. $R$. CIv. P. 54(d)(1). The rules on appeal are the same as in the first instance. FED. R. APP. P. 39.

Costs include modest witness fees, but ordinarily do not include compensation of expert witness, since most experts are presented by parties. Ordinarily, only when experts are appointed by the court do allowed costs include expert compensation. See 28 U.S.C. § 1920 (3) \& (6). Costs are regulated by statute. See, e.g., FED. R. Civ. P. 54; N.Y. C.P.L.R. 8101-8110, 8201-8204, 8301-8303a.

Attorneys' fees, on the other hand, are subject to a different practice. Only exceptionally must losing parties pay attorneys' fees of prevailing parties. $C f$. FED. R. Crv. P. 54(d)(2). By tradition and, above all, in absence of statutes directing awards, with only a few minor judge-made exceptions, the practice is that there is no reimbursement for attorneys' fees. ${ }^{3}$

Since the vast majority of all cases end without judgment, most with settlements, court decisions on fees in ordinary cases are uncommon. While costs and attorneys' fees are included within these settlements, settlements are usually private arrangements among parties with no required formalities. Court decisions on fees under certain special statutory regimens are, however, common. We discuss those regimens in Sections II (Exceptions) and Section V.C. (Class Actions).

\section{A. Terminology}

The practice of not indemnifying prevailing parties for their attorneys' fees is known in the United States as the "American rule." It is not a true rule, since rarely is the practice compelled by statute or by court decision; it is a practice that continues to exist because no general law compels the contrary. In order to avoid suggesting that it is a rule, I use different terminology to identify what others call the American rule. I call it the "no-indemnity practice." I thereby avoid implications that the practice is uniform, or that it exists without exception or that it extends beyond attorneys' fees to encompass costs as well.

A rule that permits indemnity to prevailing parties is commonly called in the United States the "English rule." Likewise to avoid confusion, I do not use that term. Instead I speak of indemnity rules or of

3. See Alyeska Pipeline Service Co. v. The Wilderness Society, 421 U.S. 240, 247 (1975) ("[W]e are convinced that it would be inappropriate for the Judiciary, without legislative guidance, to reallocate the burdens of litigation . . . ."). 
loser-pays rules, using both interchangeably. Indemnity rules are common and few, if any, are identical to the rules in England, which themselves are in transition. The mistaken impression that all loserpays rules are like English rules has led American critics to assume deficiencies of the English rule are characteristic of indemnity rules generally. ${ }^{4}$

\section{B. Rationale for the No-Indemnity Practice}

The rationale most often given for the no-indemnity practice is to provide access to courts for poor and other risk-averse persons. ${ }^{5} \mathrm{We}$ are indebted to Professor Leubsdorf for the observation that the rationale post-dates the practice. (He calls it a "pure anachronism."6) Perhaps that is not surprising. While rules are adopted as deliberative acts, practices grow organically.

The U.S. Supreme Court endorses the view that the no-indemnity practice promotes access to courts. It explained: "[s]ince litigation is at best uncertain, one should not be penalized for merely defending or prosecuting a lawsuit ... [T] he poor might be unjustly discouraged from instituting actions to vindicate their rights if the penalty for losing included the fees of their opponents' counsel."7 Indemnifying prevailing parties would discourage plaintiffs with plausible, but not clearly winning lawsuits, from suing. ${ }^{8}$ Worse, they might bring a lawsuit, be heavily outspent by the better off adversary, and find themselves compelled upon defeat to indemnify their adversaries for attorneys' fees.

Here we must step back a moment for a word of explanation for readers not familiar with American litigation. In the United States there are no general laws that keep attorneys' fees in proportion to amounts in dispute. In the United States, attorneys' fees are largely

4. See George B. Shepherd, The Impacts of the Fee-Shifting on Litigation Behavior, Balancing Interests, Liber Amicorum Peter Hay Festschrift Peter Hay 381 (2005).

5. See John F. Vargo, The American Rule of Attorney Fee Allocation: The Unjured Person's Access to Justice, 42 AM. U.L. REv. 1567, 1594 (1993),

6. John Leubsdorf, Toward a History of the American Rule on Fee Recovery, 47 Law \& Contemp. Problems 9, 10 (1984). He also suggests that its original adoption resulted from inability of the American bar at the time to get statutory fees increased.

7. Fleishmann Distilling Corp. v. Maier Brewing Co., 386 U.S. 714, 718 (1967). Some judges indentify the rule with democracy and the right to be heard. See, e.g., Mihalik v. Pro Arts, Inc. 851 F. 2d 790 (6th Cir. 1988) ("It]he American Rule has been perpetuated because it represents a democratic ideal. Unfettered access to the courts for all citizens with genuine legal disputes has become a cornerstone of the American concept of justice. All persons are entitled to their day in court, however poor they may be and however rich their opponents.").

8. Cf., Matthew J. Wilson, Failed Attempt to Undermine the Third Wave: Attorney Fee Shifting Movement in Japan, 19 EMORY INT'L L. REv. 1457, 1462 (2005) ("Because Japan and the United States are virtually alone ... this rule might be referred to as the "American-Japanese" Rule.") See also, id. at 58 (referring to parties with "viable" claims not suing.). 
uncontrolled. Lawyers-and not judges-largely shape the course of litigation. Lawyers-and not judges-largely determine how much time goes into any one lawsuit. Since time literally is money-today most American lawyers bill based on time ${ }^{9}$-lawyers in effect set attorneys' fees for both sides. No fee tables limit lawyers' fees. As a result, it is not uncommon for parties' combined legal bills to equal or exceed amounts in controversy. ${ }^{10}$

It is this world of unbounded attorneys' fees that American lawyers inhabit when they contemplate a loser-pays alternative. Not without justification they fear that impecunious plaintiffs who have temerity to sue wealthy defendants, particularly corporate defendants, will be over-spent and overwhelmed by their adversaries' superior arms; ${ }^{11}$ when vanquished they will be compelled to pay for their folly by reimbursing their adversaries for the attorneys' fees that they themselves could not afford. ${ }^{12}$

American lawyers' fears of an indemnity world may be heightened by their experiences with the limited indemnity rules that they do have. Litigation over attorneys' fee indemnity can cost more than the original fees. The U.S. Supreme Court in denigrating a general loser-pays rule observed: "the time, expense, and difficulties of proof inherent in litigating the question of what constitutes reasonable attorney's fees would pose substantial burdens for judicial administration. ${ }^{13}$ The Court was not contemplating foreign alternatives, such as the German fixed recoverable costs system, where recoverable costs are easily predicted beforehand.

American reluctance to embrace a loser-pays rule, such as prevails in much of the world, is also in part attributable to a ten-

9. The principal exception is the contingent fee system discussed below.

10. This phenomenon is well-known to practitioners-I experienced it myself in more than one case - and to the public at least since 1853 when Charles Dickens told of the infamous fictitious case of Jarndyce $v$. Jarndyce in BLEAK HOUSE:

"[O]n the numerous difficulties, contingencies, masterly fictions, and forms of procedure in this great Cause, there has been expended study, ability, eloquence, knowledge, intellect . . . . [I]t must be paid for in money . . .." costs?"

"Do I understand that the whole estate is found to have been absorbed in

"Hem! I believe so." ... .

"And that thus the suit lapses and melts away."

Chap. LXV. A recent announcement for a bar program puts it succinctly: "At times, attorneys' fees exceed the amount in dispute and become the litigation 'tail that wags the dog." Santa Clara County Bar Association, Program on Costs, Fees and Statutory Offers, April 23, 2008, available at http://www.calegaladvocates.org/calendar/event. 188433-Costs_Fees_and_Statutory_Offers.

11. See Vargo, supra note 5, at 1595-1596.

12. Of course, one way to avoid this problem would be to limit the reimbursable amount. See the discussions in Section VII.

13. See, e.g, Fleishmann Distilling Corp. v. Maier Brewing Co., 386 U.S. at 718. See also Marshall J. Breger, Compensation Formulas for Court Awarded Attorney Fees, 47 Law \& Contemp. Problems 249 (1984). 
dency among American lawyers to see lawsuits as events divorced from the rights and duties that lawsuits determine. ${ }^{14}$ Instead of seeing indemnity as a natural consequence of a judicial determination that one party is in the right and the other is not, they see indemnity as a penalty imposed for choosing to obtain a judicial determination of that right. Indemnity, they believe, imposes "strict liability without fault for unsuccessfully suing or defending a claim." 15 Of course, that tendency is strengthened if the indemnity is at a ruinous rather than at a modest level.

\section{EXceptions ANd Modifications}

\section{A. Exceptions}

Although no-indemnity is a matter of practice and not of rule, most exceptions to it are not judge-made, but are products of legislation or of private agreement. When it comes to issues of attorneys' fees, American courts defer to statutory enactment and to party choice. The few judge-made exceptions to the no-indemnity practice address particular factual situations that are unlikely to be of sufficient interest to find mention in the general report. ${ }^{16}$ Below, in a later section, we discuss when parties choose in their contracts to adopt an indemnity rule in dispute resolution; in this section we discuss exceptions created by statute.

\section{One-way fee shifting statutes}

There are said to be over two thousand statutes that impose statutory exceptions to no-indemnity practice. ${ }^{17}$ While a few such statutes impose a general loser-pays rule, ${ }^{18}$ most provide only for socalled "one-way fee shifting." In one-way fee shifting one side is entitled to attorneys' fees if that side wins (most typically the plaintiffs'

14. See Mark S. Stein, Is One-Way Shifting Fairer than Two-Way Shifting?, 414 F.R.D. 351 (1992) (an exception that makes the point about conflicting claims of right). See also Joshua P. Davis, Toward a Jurisprudence of Trial and Settlement: Allocating Attorney's Fees by Amending Federal Rule of Civil Procedure 68, 48 ALA. L. REv. 65, 72-75 (1996) (suggesting three characterizations of trial and settlement, all of which are divorced from the claim of right).

15. Thomas D. Rowe, Jr., Indemnity of Compensation? The Contract with America, Loser-Pays Attorney Fee Shifting, and a One-Way Alternative, 37 WASHBURN L.J. 317, 321 (1998).

16. See, e.g., Vargo, supra note 5, at 1578-1587 (discussing, inter alia, "common fund," "substantial benefit doctrine," "contempt" and "bad faith"); Alyeska Pipeline Service Co. v. The Wilderness Society, supra, 421 U.S. at 257-259 (stating "These exceptions are unquestionably assertions of inherent power in the courts to allow attorneys' fees in particular situations, unless forbidden by Congress."); Chambers v. NASCO, Inc., 501 U.S. 32 (1991) (holding court has inherent authority to impose attorneys' fees as sanction for bad faith in litigation).

17. Id. at 1629 .

18. See Harold J. Krent, Explaining One-Way Fee Shifting, 79 VA. L. REv. 2039, 2051 n.48 (1993) (citing examples). 
side), but if that party loses, ordinarily that party is not subject to a claim from the other side for attorneys' fees. These statutory exceptions to the no-indemnity practice are designed to, and usually do, encourage lawsuits. ${ }^{19}$

The great majority of one-way fee shifting statutes implement public policy by encouraging non-governmental actors to act as "private attorneys general" in the enforcement of public law norms. These statutes are found throughout public law in areas as disparate as racial discrimination, crime control, taxation, and market regulation. Of course, the statutes need not have used the vehicle of oneway fee shifting to encourage private attorneys general bringing suit. The incentive they did use, as we shall shortly see, is directed principally to plaintiffs' attorneys. Older and more well-known incentives that they might have used would have been directed to plaintiffs themselves, e.g., a share in the government's recovery (so-called qui tam actions), enhanced private damages (treble damages) or punitive damages.

One-way fee shifting statutes encourage litigation in cases that are not likely candidates to produce high-dollar judgments, either because relief sought is non-monetary or because only modest amounts of money are at stake. ${ }^{20}$ Such cases would not normally be candidates for contingent fee representation (see section below), because there is not enough money at the end of the line to pay plaintiffs' attorneys their fees. Introduce one-way shifting, and now there is money for attorneys' fees. These cases become comparable to contingent fee cases, that is, clients have no downside risks and, therefore, no reason not to sue. ${ }^{21}$ There is no downside risk for clients and the only risk for lawyers is their own time and money. Change those same cases further into two-way fee shifting case, and you strip them of contingent-fee comparability. Now clients with modest claims or seeking non-monetary relief will care; they will avoid litigation if they possibly can. ${ }^{22}$

There is no single law that governs one-way fee shifting statutes. The Supreme Court has observed that they "differ considerably among themselves." One practitioner's treatise divides them into nineteen different classes spread over three thick loose-leaf volumes. ${ }^{23}$ Most are rudimentary in the instructions they give to facilitate their application. For example, one of the more important, the

19. Alyeska Pipeline Service Co. v. The Wilderness Society, 421 U.S. at 261-263. Breger, supra note 13, at 251.

20. Krent, supra note 18, at 2048-2054.

21. See Brandon Chad Bungard, Fee! Fie! Foe! Fum!: I Smell the Efficiency of the English Rule: Finding the Right Approach to Tort Reform, 31 Seton Hall Legisl. J. 1,7 n. 26 (2006).

22. Id. at 2050 n. 48.

23. Alba Conte, Attorney Fee Awards (3rd ed., 4 loose-leaf volumes, last updated 2009). 
Voting Rights Act of 1965, provides only: "the court, in its discretion, may allow the prevailing party . . . a reasonable attorney's fee . . ." 42 U.S.C. $\$ 1973 l(\mathrm{e})$. Their very variety suggests that not plan but particularist interests are behind each one individually.

\section{B. Mandatory Pre-Litigation Procedures (e.g., Arbitration)}

In different statutes the U.S. Congress has given local federal courts authority to adopt mandatory arbitration or mediation procedures. E.g., Civil Justice Reform Act of 1990, Alternative Dispute Resolution Act of 1998. I have not reviewed these local rules, but I do not believe that many, if any, introduce new rules regarding costs or attorneys' fees.

\section{Agreements Allocating Costs and Fees}

Agreements allocating costs and fees are permissible ${ }^{24}$ and have been accepted for a long time. ${ }^{25}$ Sometimes they have been controlled by statute. Other times, when sought enforced, they have been subject to case-by-case control as unconscionable contract terms where deemed one-sided. ${ }^{26}$ The generally weak level of American control of unconscionable contract terms (not, as in Europe, unfair terms), means control of such terms is exceptional. ${ }^{27}$

\section{Self-Representation (pro se)}

Federal law, first adopted in $1789,{ }^{28}$ permits parties in federal court to "plead and conduct [their] own cases personally." 28 U.S.C. $\$ 1654 .{ }^{29}$ That right is recognized throughout the United States and is known as a right to pro se representation. While the right to proceed pro se is seen as "a basic right of a free people," 30 its rationale today is more pragmatic: to provide access to justice.

24. See, e.g., Zuver v, Airtouch Communications, Inc., 153 Wash. 2d. 293, 103 P. 3d 753 (2004).

25. See Annotation, Validity of provision in promissory note or other evidence of indebtedness for payment, as attorneys' fees, expenses, and costs of collection, of specified percentage of note, 17 A.L.R.2d 288 (1951).

26. See, e.g., Sosa v. Paulo, 924 P. 2d 357 (Utah 1996) (patient against physician, substantively unconscionable because required plaintiff to pay if awarded less than half claim).

27. See James R. Maxeiner, Standard Terms Contracting in the Global Electronic Age: European Alternatives, 28 YALE J. INT'L .L. 109 (2003).

28. $\S 35$ of the Judiciary Act of 1789 .

29. See Tiffany Buxton, Foreign Solutions to the U.S. Pro Se Phenomenon, 34 Case W. Res. J. InT'L L. 103 (2002); Drew Swank, Note and Comment: The Pro Se Phenomenon, 19 BYU J. PUb. L. 373 (2005); Nina Ingwer Van Wormer, Note: Help at Your Fingertips: A Twenty-First Century Response to the Pro Se Phenomenon, 60 VAND. L. REv. 983 (2007).

30. O'Reilly v. New York Times Co., 692 F.2d 863, 867 (Friendly, C.J.) ("The Founders believed that self-representation was a basic right of a free people."). 
In the United States there is no general right to a lawyer in civil cases. Lassiter v. Dept. of Social Services, 452 U.S. 18 (1981). The right to proceed alone, without a lawyer, i.e. pro se, thus is essential to participation in legal proceedings. Were there no right to pro se representation, the United States would either have to provide the indigent with legal representation (civil legal aid), or it would deny people the right to be heard.

Except in small claims courts, self-representation is not common in civil cases. Existing procedures are not set up to facilitate pro se representation. On practical grounds most parties obtain legal counsel. The active role of attorneys and the passive role of judges practically preclude pervasive employment of pro se representation. Greater use of self-representation would require that courts provide new services and assist pro se litigants in ways that they have not previously assisted parties. ${ }^{31}$

\section{Encouragement or Discouragement of Litigation}

Whether American cost and fee allocation rules encourage or discourage a particular lawsuit depends upon the type of case and upon the concerns of the potential plaintiff. Is the potential plaintiff more concerned about the cost to get in, the cost to stay in, or the value to be gotten out of the lawsuit? ${ }^{32}$ American lawsuits are often compared to lotteries ${ }^{33}$ and, in this respect, they do look like lotteries. Like most lotteries, the price of admission is low. Like players in most lotteries, many plaintiffs hope for big wins. Like players in most lotteries, most plaintiffs are disappointed: they walk away with little or nothing other than the pleasure (?) in playing the game.

Most studies of American cost and fee allocation conclude that low costs and no-indemnity practice compared to loser pays encourage lawsuits of low merit and discourage lawsuits of substantial merit. ${ }^{34}$

31. See generally The Future of Self-Represented Litigation: Report From THE MARCH 2005 SUmmit (National Center for State Courts, 2005), available at www. ncsc.org.

32. See, e.g., Robert G. Steiner, Getting In, Getting Out, Getting Paid (1981).

33. See, e.g., AN ACCIDENT AND A DREAM: HOW THE LAWSUIT LOTTERY IS DISTORTING Justice and COSTING New Yorkers billions of Dollars Every year (Public Policy Institute, 1998); Douglass S. Lodmell \& Benjamin R. Lodmell, The Lawsuit Lottery: The HiJacking of Justice in America (2004); Jefrrey O'Connell, The LAWSUIT LOTTERY (1979).

34. See Marie Gryphon, Greater Justice, Lower Cost: How a "Loser Pays" Rule Would Improve the American Legal System, Civil Justice Report, No. 11 (Manhattan Institute, December 2008) [Emphasis in original]. With respect to contingent fee lawsuits, Herbert Kritzer speaks of "a cross-subsidy among clients. The client who turns out to have a very good case subsidizes the client whose case turns out to be a dog." KRITZER, RISKS, infra note 45 , at 260. 
Court costs, including filing fees, are low. Even the federal case, the luxury model lawsuit, costs only $\$ 350$ to enter, no matter how low or high the claim is. 28 U.S.C. $\S 1914$. That is surely by design.

Attorneys' fees, on the other hand, are more complicated. How much parties have to pay up front to their lawyers in the form of retainer fees is entirely a matter of practice. It varies from lawyer-tolawyer and case-to-case. Above all, it depends upon whether the lawyer works on a contingent fee, no fee or non-contingent fee basis (i.e., flat rate or hourly rate) or some combination of non-contingent and contingent fees. In the following section we discuss these different types of fees. When attorneys' fees are not contingent and plaintiffs must advance them upfront, those fees must discourage lawsuits. How much is an individual matter. Individual lawyers are free to require as high or low retainers as they see fit. We discuss contingent fees below.

The no-indemnity practice permits, and by permitting encourages, inflating claims, since there is no sanction for parties who claim a lot and win little or nothing. Wildly inflated claims are common. I personally was sued for more than $\$ 300,000$ for a slip-and-fall accident that occurred in my house and resulted in medical bills below $\$ 20,000$; after three depositions the insurance company settled for nuisance value of around $\$ 7000$. In the most notorious recent case the plaintiff, who happened to be a judge, sued for $\$ 54$ million from a drycleaner who lost a pair of pants. The drycleaner "won", but only after paying nearly $\$ 100,000$ in non-recoverable legal fees. ${ }^{35}$

\section{The Determination of Costs and Fees}

\section{A. Determination of Court Costs}

Court costs are determined by statutory lists of charges imposed for a handful of matters. Federal law, 28 U.S.C. $\S 1920$, limits these charges to six specific types of expenses listed in the margin. ${ }^{36}$ These charges are independent of the amount in controversy and, except in unusual cases where court-appointed experts or interpreters are used heavily, are trivial compared to attorneys' fees. The statutory list is exclusive and has not permitted inclusion of other expenses, such as

35. Id. at 2.

36. "(1) Fees of the clerk and marshal; (2) Fees for printed or electronically recorded transcripts necessarily obtained for use in the case; (3) Fees and disbursements for printing and witnesses; (4) Fees for exemplification and the costs of making copies of any materials where the copies are necessarily obtained for use in the case; (5) Docket fees under section 1923 of this title; (6) Compensation of court appointed experts, compensation of interpreters, and salaries, fees, expenses, and costs of special interpretation services under section 1828 of this title." 28 U.S.C. $\S 1820$. 
costs of electronic legal research charges. ${ }^{37}$ New York State practice is similar.

Typically, the winning party prepares a bill of costs and submits the bill to the clerk of the court, who then reviews and approves it. Judicial involvement is exceptional.

\section{B. Determination of Attorneys' Fees: The Role of "Pretrial"}

Attorneys' fees are determined by agreements between lawyers and their clients. They are not mandated and are only exceptionally controlled by law. The principal control is that in some jurisdictions the percentage of a recovery subject to a contingent fee is limited.

\section{Fee Calculation Methods: Flat Rate, Contingent, and} Hourly Billing

Historically, American lawyers have charged fees in variations of three principal approaches: (1) task-based flat fees; (2) success-based contingent fees; and (3) time-based hourly fees. When cost shifting was more common in the early part of the nineteenth century, fees were principally task-based. The success-based contingent fees became popular only in the latter part of the nineteenth century. ${ }^{38}$ Time-based hourly fees became common only in the 1950s and 1960s when pre-trial discovery began to be widely used. ${ }^{39}$

\section{Generating Fees: Discovery}

The introduction of the Federal Rules of Civil Procedure in 1938 proved enormously important for American civil procedure in general and for generation of attorneys' fees in particular. Since adoption of the federal rules in 1938, the focus of American litigation has moved from trial practice to pre-trial discovery. Trial has vanished and pretrial procedures have replaced it. ${ }^{40}$ Although many cases are settled without substantial pretrial discovery, most settle in its shadow.

Pretrial discovery knows few bounds. ${ }^{41}$ It leaves the lawyers to be the judges of what they shall do. But worse than that, it leaves to

37. Sarah Wise, Comment: Show Me the Money! The Recoverability of Computerized Legal Research Expenses by the Prevailing Party in the Federal Circuits. 36 CAP. U.L. REv. 455, 480 (2007).

38. See Peter Karsten, Enabling the Poor to Have Their Day in Court: The Sanctioning of Contingency Fee Contracts, A History to 1940, 47 DePaul L. Rev. 231 (1998).

39. See William G. Ross, The Honest Hour: The Ethics of Time-Based Billing By AtToRneys 9 et seq (1996) (2nd ed. forthcoming).

40. See Robert P. Burns, The Death of the American Trlal (2009).

41. The permissible scope of discovery extends to any matter "that is relevant to any party's claim or defense," is not limited to information admissible at trial, and can extend to "any matter relevant to the subject matter involved in the action." Fed. R. Civ. Pro. 26(b)(1). Recently imposed limitations on quantity of discovery are meaningful only in larger cases. Without leave of the court, each side may order up to ten 
them to be judges of what their adversaries shall do. Under federal discovery rules and their counterparts in the states, lawyers, often at little cost to themselves or their clients, can compel their adversaries and their clients to make burdensome discovery of documents and participate in pointless depositions. It takes little imagination for a lawyer determined to do so, to render a plaintiff's modest- to even large-sized claim for compensation of little value. ${ }^{42}$

\section{Judicial Determination of Attorneys' Fees}

As we have seen, in most American cases there is no fee-shifting and no occasion for courts to determine fees. Cases where courts are involved in determining attorneys' fees are statutes permitting "oneway" fee shifting, i.e., losing defendants pay, but losing plaintiffs do not. We saw that there is a plethora of one-way fee shifting statutes. Most provide little direction to courts for determination of fees.

It is not surprising that given such little statutory direction, there is what one appellate panel including former Supreme Court Justice O'Connor characterized as "confusion" in fee-setting jurisprudence. While American courts have not all coalesced behind the details of how to determine a reasonable fee, they start from the same assumption; the initial measure should be the billing approach of American lawyers generally: ${ }^{43}$ number of lawyers' hours spent multiplied by a reasonable hourly rate (the "lodestar" approach). Where they diverge is how they apply that calculation. Some say a reasonably hourly rate is that of lawyers in the vicinity of the court ("forum rule"); others say it should be the rate of lawyers brought in from more expensive areas. Some say the lodestar amount should be the measure; others say that the lodestar amount should only be a "presumptively reasonable," to be adjusted by other factors, including by such a measure as what a "reasonable client would be willing to pay." 44 Notwithstanding the latter check, all approaches start from the perspective of lawyers who invest time in bringing lawsuits, and not from the perspective of paying clients who calculate what they have to gain-usually based on amounts in controversy.

depositions of seven hours each. Fed. R. Civ. P. 30(a)(2)(A)(1). It is said that those limits are easily waived in larger cases.

42. Before the Federal Rules lawyers had similar opportunities with pre-trial motions, but these were not as extensive as with discovery. Similar opportunities still exist.

43. See generally supra note 39 .

44. See Arbor Hill Citizens Neighborhood Association v. County of Albany, 493 F.3d 110 (2nd Cir. 2007). 
V. Special Issues: Success-Oriented Fees, Class Actions, Sale of Claims, and Litigation Insurance

\section{A. Success-Oriented Fees}

The principal form of success-oriented fees in the United States is the pure contingent fee. In pure contingent fees lawyers receive fees if, and only if, they prevail for their clients. ${ }^{45}$ Then they receive their fees, not from plaintiffs, but from the money that they recover for their clients. Plaintiffs benefit because they have no downside risk from lawsuits: win or lose they need pay neither their attorneys' fees nor their adversaries' attorneys' fees. Plaintiffs' attorneys benefit because they have no difficulty collecting fees, even very large ones, so long as they are successful. Not every lawsuit permits contingent fee representation, but when lawsuits do so allow, individuals prefer contingent fees. ${ }^{46}$

Contingent fee representation is available only in certain situations. In most lawsuits, it is not available to defendants to fund representation, since in most lawsuits defendants do not recover money judgments. Likewise, contingent fee representation is not available to plaintiffs who do not seek money damages, since pure declaratory relief does not produce money from which lawyers can be paid. ${ }^{47}$ Nor does it work well with those claims for small amounts which, unless aggregated ("class actions"), are too small to generate sufficient funds to cover litigation expenses.

Because of the absence of downside risk, many, perhaps most individuals prefer contingent fee representation when they can get it. ${ }^{48}$ We saw in Subsection II.A., above, that one-way fee shifting statutes approximate the effect of contingent fee representation for claims for non-monetary relief, for claims for small amounts, and for defendants' claims, in those rare instances where the one-way is the defendant's way. Two-way fee shifting, i.e., loser-pays, of course does not approximate those effects. Indeed, loser-pays undercuts plaintiffs' principal reason for choosing contingent-fee representation: the absence of down-side risk.

Contingent fees have long been controversial, but have been part of American civil litigation for well over a century. Scholars debate not the acceptance of contingent fees, but the timing of their widespread adoption. They certainly found wide application-if not

45. See generally, Herbert M. Kritzer, Risks, Reputations, and Rewards: Contingency Fee Legal Practice in the United States 9-10 (2004).

46. Herbert M. Kritzer, The Justice Broker: Lawyers and Ordinary LitigaTION 58 (1990).

47. The rule that prefers money damages over specific performance does mean that contingent fee recovery is available more often than it would be in systems that favor specific performance over damages.

48. KRItZER, The Justice BROKER, supra note 46. 
always approval-by the turn of the twentieth century. Just when in the nineteenth century they became common and not exceptional is at issue. 49

Contingent fee representation is available only to those parties, almost always plaintiffs, who are able to persuade lawyers to "take their case." For most lawyers most of the time, taking a case is a risk decision. ${ }^{50}$ Principal factors in taking or declining a case are three: proof of plaintiff's damages, proof of defendant's liability and the lawyer's practice area. Herbert Kritzer calls these the "three ' $R$ ' factors: risks, rewards, and reputations." He reports that among those lawyers he studied, of decisions to decline representation $47 \%$ were based on absence of defendants' liability alone, $19 \%$ on insufficient plaintiffs' damages alone, $13 \%$ on defendants' liability and plaintiff's damages both, $11 \%$ on being outside their practice area, and $11 \%$ on other grounds. ${ }^{51}$ From the lawyer's perspective, the ideal contingent fee case is in the lawyer's practice area, is easy to prove, and produces large damages. Conversely the baneful case is outside the lawyer's practice area, is difficult to prove, and produces modest or no damages.

Assumed in discussions of contingent fee representation is the open-ended nature of American legal fees. When limitations on contingent fees are discussed, usually they are couched in terms of the percentage of the eventual recovery that the contingent fee lawyer may take. Thirty-three percent is the usual benchmark, but percentages may be higher or lower or variable. ${ }^{52}$

Based on my practice experience and other observation, but on no studies that I can cite, I believe that contingent fee representation, when coupled with the open-ended nature of American legal fees, cause plaintiffs' lawyers working on contingency to prefer similarly open-ended claims (such as tort cases with huge damages, mental damages, pain-and-suffering and the like) over determinate claims (such as many contract claims). That is, if the amount of recovery is limited, for example, to the amount flowing from a breach of contract where there is no possibility of consequential or otherwise open-ended damages, then a contingent fee is not attractive. The side opposing the claim can force the plaintiff's lawyer to spend it into oblivion.

Not surprising, contingent fees are mostly a feature of tort claims on behalf of individual plaintiffs. According to one of Kritzer's stud-

49. See Peter Karsten, Enabling the Poor to Have Their Day in Court: The Sanctioning of Contingent Fee Contracts, A History to 1940, 47 DePaur L. REv. 232 (1998); Stephan Landsman, The History of Contingency and the Contingency of History, 47 DePaul L. Rev. 261 (1998).

50. John A. Day, Should you risk taking the case?, TRIAL, January 2008, at 20.

51. KRITZER, RiSks, supra note 45, at 84-89 (note Table 3-9).

52. KRITZER, RISKs, supra note 45 , at 37-44. 
ies, most individual parties have contingent fee arrangements, while most organizational parties have hourly fee arrangements. ${ }^{53}$ Their use in contracts claims is less common. If I am correct in my belief, a study might show that that contingent fees in contract cases are used principally in very simple cases where liability is practically conceded (e.g., collection cases for unpaid and undisputed invoices) ${ }^{54}$ and in those cases where open-ended damages are possible (e.g., consequential damages). This may be one reason why in contract litigation lawyers try to find a tort upon which to base an open-ended punitive damage claim.

I am no psychologist, but I also believe that contingent fees applied to open-ended claims would be more socially acceptable than when applied to determinate claims. In the former case, if, as Professor Kritzer put it, "the case proves to be a 'real winner,' the lawyer will share in that good fortune,"55 in the latter case, the lawyer who takes thirty-three percent or more of plaintiffs' recovery appears to the public to be a blood-sucking leech.

\section{B. Financing Litigation through Sale of Claims}

In recent years a litigation financing industry has grown up in the United States. It does not, however, include selling claims for purposes of litigation. The prohibition on champerty, found in New York at section 489 of the Judiciary Law, prohibits selling of claims "with the intent and for the purpose of bringing an action or proceeding thereon." Lawyers are under an obligation, found in Disciplinary Rule 5-103 of the American Bar Association's Model Code of Professional Responsibility (1983), not to acquire a "proprietary interest in the cause of action." (The rule explicitly exempts contingent fee representation from this provision.) The code of best practices of the American Legal Finance Association, a trade association, explicitly provides that its members will not acquire ownership interests in consumers' litigation. ${ }^{56}$

The industry does not buy claims; it lends money at high rates in non-recourse loans with the expectation of recovering the loan plus interest from the eventual settlement of the lawsuits. Borrowers who recover nothing, are not obligated to repay. According to the trade association, most of its members do not extend loans for more than ten percent of the estimated values of cases. ${ }^{57}$ The Attorney General

53. Kritzer, The Justice Broker, supra note 46, at 58-59.

54. The professional organization for lawyers doing collection work is the Commercial Law League of America. See its website at http://www.clla.org/.

55. Kritzer, The Justice Broker, supra note 46.

56. "Industry Best Practices - ALFA's Code of Conduct, No. 2," available at http:// www.americanlegalfin.com/IndustryBestPractices.asp.

57. FAQ, "Is it harder to settle a case with a non-recourse advance in place?," available at http://www.americanlegalfin.com/faq.asp. 
of the State of New York has given state sanction to the practice, so long as the loans are accompanied by adequate disclosures. ${ }^{58}$ Nevertheless, a New York State Court of first instance found one such loan illegal. The court determined that the loan did not constitute champerty, because it was made only after litigation was commenced. The court nevertheless set the loan aside on different ground: usury. The loan provided for interest of $3.85 \%$ per month compounding monthly. The court rejected the lender's argument that since the loan was nonrecourse, i.e., the borrower had no obligation if the claim failed, it could not constitute usury, since lender shared the risk. Here, the court found, there was no risk and that meant that the loan was subject to usual lending standards. ${ }^{59}$

\section{Class Actions}

Class actions ("aggregate litigation") are presented as one way to facilitate contingent fee representation for small claims. Since 2003, the Federal Rules of Civil Procedure in Rule 23(h) have required that courts, as part of their approval of class action settlements, decide on the "reasonable attorneys' fee" to be allowed. ${ }^{60}$ The method for determination of that amount follows the approach of determination under the one-way fee shifting statutes discussed above in Subsection II.A. The 2003 Advisory Committee notes that the new rule takes no position on whether that fee should be determined by the "lodestar" hourly basis or on a percentage of recovery basis.

\section{Legal Insurance}

While there have been attempts to provide legal insurance in the United States, these have found little application in providing insurance to plaintiffs. What may be the largest provider of legal insurance is ARAG Legal Solutions, a subsidiary of the German firm Allgemeine Rechtsschutz-Versicherungs Aktien Gesellschaft. ${ }^{61}$

58. Press Release, "Personal InJury Cash Advance Firms Agree to Reforms," http://www.oag.state.ny.us/media_center/2005/feb/feb28a_05.html.

59. Echeverria v. Estate of Linde, NO. : 018666/2002 (N.Y. Supreme Court, Nassau County, 2005). For discussions of this decision see Anthony J. Sebok, A New York Decision That May Imperil Plaintiffs' Ability to Finance Their Lawsuits: Why It Should Be Repudiated, Or Limited to Its Facts, FindLaw (2005) http:// writ.news.findlaw.com/sebok/20050418.html (with hyperlink to decision); Susan Lorde Martin, Litigation Financing: Another Subprime Industry That Has a Place in the United States Market, 53 VILL. L. REv. 83, 93-95 (2008). For further information on the practice, see Susan Lorde Martin, The Litigation Financing Industry: The Wild West of Finance Should be Tamed not Outlawed, 10 Fordham J. CorP. \& Fin. L. 55 (2004); Julia H. McLaughlin, Litigation Funding: Charting a Legal and Ethical Course, 31 VT. L. Rev. 615 (2007).

60. See generally Jonathan R. Macey \& Geoffrey P. Miller, Judicial Settlement of Class Actions, 1. J. Legal Analysis 167 (2009).

61. See www.araggroup.com. 
Liability insurance for defendants, on the other hand, is common. Medical doctors would not practice without malpractice insurance; automobile owners are not allowed to drive without liability insurance; homeowners cannot get mortgages without homeowner's liability insurance. Liability insurance contracts typically provide a "duty to defend," and thus furnish defendants with de facto legal insurance for their lawsuit expenses, including attorneys' fees, in addition to indemnifying them against claims successfully made. ${ }^{62}$

In December 2008, the Manhattan Institute proposed a loserpays system for the United States. That proposal considers creation of legal expense insurance key to success. The report acknowledges that any a loser-pays plan must assure access to justice for poor and middle-income plaintiffs. It envisions legal expense insurance as the most likely mechanism to achieve that goal. ${ }^{63}$

\section{Legal AID}

\section{Civil Legal Aid}

As we saw above in Subsection II.D. on self-representation, there is no legal right to state-support for representation in civil litigation. Some Americans recognize that the United States is alone among modern nations in its near total failure to provide legal aid to indigent litigants. ${ }^{64}$ Law reform groups have focused more on obtaining judicial recognition of a constitutional right to counsel in civil actions-possibly found in state constitutions-than they have on adopting legislation. ${ }^{65}$ The American Bar Association has called upon legislatures to adopt statutes mandating legal aid in a small class of cases "where basic human needs are at stake, . . . as determined by each jurisdiction."66

Such legal aid as is available is provided mostly by private groups with a modest level of government funding through lawyers

62. The Duty to Defend, in 1 The Law of Liability Insurance $\$ 5.01$ (Matthew Bender \& Co., 2009).

63. Greater Justice, Lower Costs: How a "Loser Pays" Rule Would Improve the American Legal System 16 (Marie Gryphon, Civil Justice Report No. 11, December 2008, Manhattan Institute) available at http://www.manhattan-institute.org/pdf/ cjr_11.pdf.

64. See Earl Johnson, Jr., Justice for America's Poor in the Year 2020: Some Possibilities Based on Experiences Here and Abroad, 58 DePAuL L. Rev. 393 (2009); Raven Lidman, Civil Gideon as a Human Right: Is the U.S. Going to Join Step with the Rest of the Developed World 2006 Edward V. Sparer Symposium: Civil Gideon: Creating a Constitutional Right to Counsel in the Civil Context, 15 Temp. Pol. \& Crv. RTS. L. REv. 769 (2006).

65. See Steven D. Schwinn, Faces of Open Courts and the Civil Right to Counsel, Symposium Issue: A Right to Counsel in Civil Cases: Civil Gideon in Maryland \& Beyond, 37 U. BALt. L. REv. 21 (2007).

66. Resolution 112A, Task Force for Access to Civil Justice adopted unanimously by voice vote, available at http://www.abanet.org/media/docs/112Arevised.pdf. 
whose principal practice is as legal aid attorneys for organizations. ${ }^{67}$ It is provided as charity and not as of right. The first and oldest such private association, New York City's Legal Aid Society, was founded by immigrants from Germany. All forms of civil legal aid taken together, however, support very few civil litigants in absolute numbers. Of the nation's more than one million lawyers, only 6500 are legal aid lawyers. Of the nation's more than three hundred million people, those lawyers are expected to provide legal services for fifty to ninety million people. All legal aid programs combined are funded with less than $\$ 1$ billion; in 2007, two American law firms, each earned over $\$ 2$ billion. ${ }^{68}$

While most legal aid is provided through legal aid organizations other lawyers do provide assistance as appointed counsel for low fees (uncommon) or as volunteer counsel for no fees (pro bono). The American Bar Association's Model Rules of Professional Conduct recommend that lawyers devote at least an hour-a-week to all forms of pro bono activity. Many do none and the average is less than onehalf hour. ${ }^{69}$ That is roughly the equivalent of about 12,000 lawyers working full time.

Access to justice is a major issue in the United States. ${ }^{70}$ Contingent fees and legal expense insurance are identified as alternatives to legal aid that do not require government funding. ${ }^{71}$ As we have seen, no-indemnity practice and class actions are also justified on access to justice grounds.

\section{Litigation Costs as Barriers to Bringing Claims}

Wise American lawyers advise against giving any prediction of what likely expenses will be on both sides. It is not rare for expenses to exceed the amount in controversy. One story from small claims court makes the point dramatically. In this case a credit card company sued a person not a party to a credit agreement for $\$ 1879.83$. The putative agreement allowed the lender to recover attorneys' fees; a state statute provided that the borrower could get attorneys' fees based on the same agreement. After several appeals, the defendant's total legal fees were over $\$ 30,000$. They were not recoverable because defendant's defense was that he was not a party to the contract!72

67. See Johnson, supra note 64, at 394-398.

68. Johnson supra note 64, at 396 (Skadden, Arps, Slate, Meagher, \& Flom LLP and Latham \& Watkins LLP).

69. Kathleen Flynn Peterson, President's Page: A call to our highest ideals, 11 Trial [Journal of the American Association for Justice] No. 43 (Nov. 2007).

70. See, e.g., Editorial, Fulfilling Gideon's promise; The Justice Department's push for better legal representation for poor defendants, WASH. PosT, March 9, 2010, at A18.

71. See, e.g., KRITZKer, Risk, supra note 45, at 266.

72. Jennifer M. Smith, Credit Cards, Attorney's Fees, and the Putative Debtor: A Pyrrhic Victory? Putative Debtors May Win the Battle But Nevertheless Lose the War, 61 Me. L. REv. 171, 176-181 (2009). 


\section{Commentary and Conclusion}

\section{A. "American Exceptionalism" and Attorneys' Fee Allocation}

Contemporary American proceduralists, such as Professor Oscar G. Chase, when they explain peculiarities in American procedures compared to those procedures pertaining in the rest of the modern world, point to what they call "American exceptionalism." Their idea is that the considerable differences in American court procedures in resolving disputes compared to those in other systems have cultural origins. According to this view, those differences stem not from differences in legal culture, but from differences in general culture, that is, from differences in "a set of values and understandings that generally shared by the populations that constitutes the nation."73 In other words, fundamental values are different. By implication, learning drawn from foreign legal institutions has little applicability in such instances.

Professor Chase cheerfully acknowledges that his thesis is controversial. Certainly it is not universally held among American proceduralists, although I suspect that some of those who deny it in principle, nevertheless adhere to it in practice. One noted proceduralist who explicitly rejected the idea, was Edson R. Sunderland. Sunderland was the principal drafter of the pretrial discovery provisions of the Federal Rules of Civil Procedure. That is remarkable because Chase identifies pretrial discovery as one of four features of American procedural exceptionalism. (The other three are the civil jury, the role of the judge and the role of experts.) Sunderland thought that resistance to borrowing from foreign institutions had a certain justification in substantive law, but not in legal procedure:

[In legal procedure] we have nothing to do with the principles which control social and economic relations. We are concerned solely with the methods of administration. Rules of legal procedure are no more fundamental in the law than rules for accounting in manufacture or trade. Litigation is merely a means to an end, like transportation, and the same tests should apply to both. ${ }^{74}$

While some comparativists adopt Chase's view, I do not think that many do when engaged in comparison of modern systems. In particular, I do not think that those American comparativists who

73. Oscar G. Chase, American "Exceptionalism" and Comparative Procedure, 50 Am. J. Comp. L. 277 (2002); Oscar G. Chase, law, Culture, and Ritual: Disputing Systems in Cross-Cultural Context (2005) (especially Chapter 4, "American 'Exceptionalism' in Civil Litigation.").

74. Edson R. Sunderland, Current Legal Literature, 15 A.B.A. J. 35 (1929). For a discussion of contemporary American views on social and economic aspects of litigation, see Fleming James, Jr., Geoffrey G. Hazard, Jr. \& John Leubsdorf, Civil Procedure Chapter 6 (5th ed. 2001). 
are immersed in more than one modern legal system do. While they are cognizant of differences in legal and national culture, they do not, so far as I am aware, point to differences in national culture to explain differences in procedure. They point instead to different ways that professionals approach legal problems and to the professionals themselves. Max Rheinstein, one of the most noted of the émigré emigration, who was immersed in two systems, saw the underlying cause of essential differences between common law and civil law in "the diversity of the personnel by which the machinery of justice is handled and guided."75

This is not the place to have a friendly debate with supporters of the American exceptionalism thesis. I raise the issue here only as it relates to costs and attorney fees allocation. Some contemporary proceduralists (although not Professor Chase to my knowledge), see the American no-indemnity practice as another manifestation of American exceptionalism. ${ }^{76}$

While the no-indemnity practice is peculiar to America, I do not see it as a manifestation of any fundamental cultural differences between the United States and other nations. I agree with Albert Ehrenzweig, Rheinstein's fellow émigré, who rejected the idea that our no-indemnity practice is founded on "a peculiar psychology of the American people." Ehrenzweig considered the practice to be contrary to American concern for the "little man." He compared it unfavorably to rules prevailing in totalitarian lands. He saw it as "a festering cancer in the body of our law."77

75. Max Rheinstein Comparative Law and Legal Systems, in 9 INTERNATIONAL ENCYClOPEDIA OF THE SoCIAL SCIENCES 204, 208 (1968), reprinted in 1 MaX RHEINSTEIN-GESAMMELTE SCHRIFTEN 239, 246-47 (1979).

76. See, e.g., Stephen B. Burbank, Book Review: All the World His Stage Arthur Taylor von Mehren, Theory and Practice of Adjudicatory Authority in Private International Law: A Comparative Study of the Doctrine, Policies and Practices of Commonand Civil-Law Systems, 52 AM. J. Comp. L. 741, 759 (2004); Scott Dodson, Review Essay: The Challenge of Comparative Civil Procedure, 60 Ala. L. Rev. 133, 141 (2008); Richard L. Marcus, Review Essay: Putting American Procedural Exceptionalism into a Globalized Context, 53 Aм. J. Comp. L. 709, 710 (2005); James E. Pfander, Book Review: Global Issues in Civil Procedure, 56 AM. J. Comp. L. 506, 512 (2008) ("one can see the American rule and contingency fee as a mode of financing litigation through the private sector, a choice that seems perfectly consistent with the American preference for non-state solutions to most problems").

77. Albert A. Ehrenzweig, Reimbursement of Attorneys' fees in the Great Society: In sorrow and in anger-and in hope, 54 CAL. L. REv. 792, 793, 798 (1966). Ehrenzweig did not attribute no-indemnity practice to the self-interest of lawyers and judges. The émigrés rarely spoke so openly that they might be thought to be impolite to their American hosts-at least not in English and not in the United States. Back home and in their own languages, it may have been a different story. See, e.g., Karl Loewenstein, Ketzerische Betrachtungen über die amerikanischen Verfassung, in DER StaAt als Aufgabe, Gedenkschrift FUr Max Imboden 233-54, at 250 (1972) ("The U.S. system suffers notorious deficiencies. It is an open secret that the administration of justice is one of the least exemplary aspects of American civilization, even if the understandable class-interest of established jurists-judges as well as lawyers-precludes admitting it." [Author's translation]). 
I do see contemporary American no indemnity practice as a manifestation of lawyer dominance of the American legal system. No selfrespecting Continental ministry of justice would permit its continuation. If one escapes the insular world of American litigators and assumes a comparative perspective, or even just the perspective of a client, the Rheinstein thesis of centrality of personnel as applied to attorneys' fees allocation is convincing.

- In the first place, a loser-pays principle is practically a corollary to the idea that civil procedure determines rights to resolve disputes according to law to make wronged parties whole; that indemnity is part of the claim of right is recognized in almost every modern legal system, including in the systems of the United States with respect to court costs.

- In the second place, the American rationale that the noindemnity practice promotes access to courts is a transparent, after-the-fact rationalization; access to justice is better assured in most other modern nations.

- In the third place, the history of the no-indemnity practice in American suggests that attorney self-interest was at work and not concern for fundamental principles.

We address each of these seriatim and then turn to prognostications for the future.

\section{B. The Rights Rationale of Attorneys' Fee Allocation}

The purpose of civil lawsuits is determination of rights and duties among private parties according to law. Determining rights and duties of parties resolves their disputes. If there were no civil lawsuits, private parties might use self-help to realize rights and to resolve disputes. The stronger, rather than the righteous, would prevail. To preserve peace and right, modern legal systems prohibit selfhelp except in a few limited cases. ${ }^{78}$

From this starting point it follows that parties found in civil lawsuits to be in the right should not bear the expenses of those determinations. They are right; their opponents are wrong. The opponents could have conceded the claims of right, but did not. They compelled the righteous to bring suit. Not to indemnify the righteous for those expenses concedes to defendant-opponents the power to diminish the value of those rights. A loser-pays principle should guide cost and attorneys' fee allocation, even if considerations of equity or of efficiency in some classes of cases call for departures from that guide.

78. See Thomas W. Shelton, The Spirit of the Courts 17-18 (1918). 
The loser-pays principle is recognized around the world as the principal guide to allocating costs and attorneys' fees. In the United States it is recognized as the rule in taxing costs. In some states it was (and in at least one state still is) recognized as the principle to apply to allocating attorneys' fees. In American history it was recognized by those who gave form to our civil procedure (David Dudley Field), and by those who gave form to our rules of damages and of interpretation (Theodore Sedgwick).

\section{The Vacuity of the Access to Justice Rationalization}

Proponents of American no-indemnity practice assert that it helps poor people bring claims and protects their access to justice. Ehrenzweig pointed out the twisted logic of that claim from a systemperspective. Unless the system decides cases incorrectly more often than it decides them correctly, for every person with a doubtful claim no-indemnity encourages to bring suits, more persons with righteous claims are denied the full measure of their rights.

There are better ways to encourage access to justice, and some Americans recognize that. In the literature, most point to legal aid, legal event insurance and self-representation procedures. Were we serious about improving access to justice for the poor, we would work at improving all three. Now, all exist in the United States in only the most anemic of forms. Most countries that have loser-pays also put more resources into one or more of these approaches than does the United States.

Were the United States seriously to work to improve any of these three approaches, we would discover, as England apparently did in seeking to improve legal aid, that the most important task in improving access to justice is to bring expenses down. If we want to improve the system, the most important thing we can do-even before changing allocation rules-is to keep attorneys' fees proportionate to the amount in dispute. Whether the rule is loser-pays or the practice is no indemnity, the issue of allocation is of far less consequence if the magnitude of total expenses for all parties is a modest fraction-say ten percent-of the amount in controversy.

\section{The No-Indemnity Practice and American "Culture"}

No-indemnity practice is not as deeply ingrained into American practice, let alone into common understanding, as is sometimes thought. Opposed to that idea are the rules governing costs, of which attorneys' fees once were a part. The rationalization that it promotes access to justice is seen to be "shaky at best."

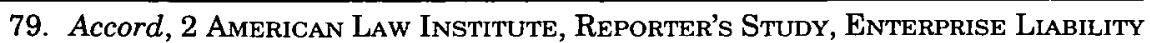
FOR PERSONAL INJURY 269-270 (1991) (also describing the rationales for the no-indem- 
The history of attorney fee allocation has yet to be written. ${ }^{80}$ Much of that history remains unclear. What seems clear, however, is that no-indemnity is a practice of the bar that worked for it and not a solution consciously chosen to meet ideals of access to justice. The latter, as we have noted, is an after the fact rationalization.

In the first half of the nineteenth century and continuing through the end of the century, some states had loser-pays rules. When the jurists whom Roscoe Pound credited with shaping American law proposed shaping the American law of cost and fee allocation, they proposed loser-pays rules. Here we speak of Theodore Sedgwick in damages and David Dudley Field in procedure. We do not here write the missing history, but we point out at modest length their proposals to challenge the idea that American values support noindemnity.

Theodore Sedgwick, Jr. is little remembered today, but he wrote the leading American treatise on damages in the nineteenth century. Its last edition appeared in 1920 and was brought up-to-date by Joseph Beale. Roscoe Pound counted Sedgwick's treatise on damages, along with Sedgwick's treatise on statutory interpretation, among a small number of treatises-half by Justice Story-that shaped American law in the pre-Civil War era. ${ }^{81}$ It is ironic and perhaps significant that Sedgwick was Alexis de Toqueville's research assistant, for Professor Chase points to de Toqueville as the first to remark upon American exceptionalism. One might well look to Sedgwick as exponent of the highest of American ideals, for he represented of the Africans who escaped from the slave ship Amistad.

In the year that the Supreme Court decided the Amistad case, Sedgwick published the first systematic American work on costs, How Shall the Lawyers Be Paid? ${ }^{82}$ Sedgwick addressed the key issues that we address today. He did not ask only, "How shall the lawyer be paid?"; he posed the "query of equal moment to the community at large, and that is, How shall the client be paid?" By that he meant,

nity practice as "shaky at best," particularly in falling short in providing full compensation to plaintiffs).

80. John Leubsdorf, Toward a History of the American Rule on Attorney Fee Recovery, 47 LAw \& Contemp. Problems 9 (1984).

81. Theodore Sedgwick, a Treatise on the Measure of Damages, or, an In. QUIRY INTO THE PRINCIPLes WHICH GOVERN THE AMOUNT OF Compensation Recovered in Suits at Law (1847, 9th ed. by Joseph Henry Beale, 1920). Roscoe Pound counted Sedgwick among just nine pre-Civil War authors and Sedgwick's two textbooks, On Damages (1847) and On Interpretation of Statutory and Constitutional Law (1857), among eighteen textbooks which "went far to shape the law." RosCOE Pound, The Formative Era of American Law 140 (1938). With two entries on Pound's list, Sedgwick tied Joel Bishop for second place; Justice Story was a clear first with nine of the titles.

82. Theodore Sedgwick, How Shall the Lawyers be Paid? Of Some Remarks upon Two Acts Recently Passed on the Subject of the Costs of legal ProceedingS IN a LETTER to JoHN ANTHON (1840). 
"shall not the client also be compensated for the vexation and delay to which he is put by the losing party, whether that annoyance be occasioned by the resistance of a just demand or by the prosecution of an unfounded claim?"83

Sedgwick faulted existing legal rules for two principal deficiencies: they sought to control fees between attorney and client, and they determined fees based on a deficient system that promoted waste. The only feature Sedgwick did like in the old laws was that losers paid. In his pamphlet Sedgwick sought to devise a "better mode." He rested his proposal on three cardinal principles (his term) that should form the basis of a modern American rule:

(1) The losing party should pay all the expenses of the litigation. Sedgwick called this a "rule of inherent justice."

(2) Those expenses should only be "fair charges," that is those expenses for a "lawyer of respectability" and not for a lawyer of "remarkable or extraordinary ability."

(3) That the losing party should pay "only for what is done, and that no more shall be done than is necessary to secure the ends of justice." The system should not create inducement for useless labor.

Sedgwick proposed a system where the successful plaintiff would get a percentage of the recovery while the successful defendant would be entitled to a percentage of the amount claimed by the unsuccessful plaintiff. That percentage would decrease as the amount in controversy increased, but would increase as the time required to resolve the case increased. Of critical importance to Sedgwick was that his system did not fix the charges that lawyers could charge their client; it controlled only the amounts that could be awarded.

Sedgwick and David Dudley Field, Jr. were associated in Field's law practice. They worked together in the 1846 revision of the New York Constitution. Whether they worked together on the cost and fee allocation provisions of the 1848 civil procedure form is not known to me, but it seems likely that Field was been aware of Sedgwick's 1840 proposal.

The Field Code of Civil Procedure adopted in New York in 1848 adopted two key principles: freedom of lawyers to agree on fees with their clients (a principle dear to the hearts of the bar) and loser-pays (a principle of less dearness to the bar). The Code's first provision on the point, section 258, repealed all laws "establishing or regulating" attorneys' fees and provided that the "measure of such compensation shall be left to the agreement, express or implied, of the parties." The balance of the Code provisions on costs set out the terms of loser-pay. The Commission's report, without qualification adhered to loser-pays

83. Id. at 4. 
and the principle of right: "The losing party, ought however, as a general rule, to pay the expense of the litigation. He has caused a loss to his adversary unjustly, and should indemnify him for it." ${ }^{44}$

From here, however, the history becomes murky. One of the first treatises on Field's Code asserted that the Code itself "obviously failed to obtain" the very object that the Commissioners had proposed. ${ }^{85}$ The terms of the Code were revised already in 1857 to make awarding attorneys' fees more difficult. Throughout the balance of the century, largely out-of-public observation, lawyers disputed over when and how fees should be awarded. When it came before the public, however, there was sympathy for making losers pay. Not long after the turn of the century, however, it seems that no-indemnity was the working rule and a true loser-pays rule was only a memory. ${ }^{86}$ So little in memory was it that it seems the issue, although subject of some interest in the academic community, was not even considered in adoption of the Federal Rules of Civil Procedure. ${ }^{87}$

\section{E. The Future-Bar Support for the Practice Today}

In the bar, the American practice is practically sacrosanct. Small wonder that it is: what is its downside for the practicing professional? The only downside is that attorneys must or should turn-away valid claims that are not financially viable. That may be particularly hard to do for a regular client. But who wants to take a claim to court only to see the legal fees equal or exceed any possible recovery? That is a common result for claims under $\$ 25,000$ and not unusual for amounts of $\$ 100,000$ or even $\$ 1$ million.

In all other respects the practice is a lawyer's delight. There is little reason not to bring a lawsuit where a nuisance recovery will make the client happy. There is little reason not to inflate a demand in the hope that it will increase the eventual settlement. And the practice offers benefits for defense counsel as well. Lawyers often grouse that physicians get to bury their mistakes. The American practice means that at least when lawyers lose, their clients are not doubly burdened with the fees that their adversaries charged. When

84. First Report of the Commissioners on Practice and Pleading: Code of Procedure 206 (1848).

85. Henry Whitaker, Practice and Pleading under the Codes, Original and Amended, with ApPendix of Forms 600 (1852).

86. See, e.g., Joseph L. Prager, Letter to the Editor: Too Much Litigation: Relieving Our Overcrowded Courts by Making Unnecessary Appeals to Law More Costly for the Defeated Party, N.Y. Times, Jan. 9, 1923 (recalling a former practice said to have been applied in almost every case to allow five percent of the amount in dispute after trial).

87. See, e.g., Charles T. McCormick, Attorneys' Fees and Other Expenses of Litigation as an Element of Damages, 15 MinN. L. REv. 619, 642 (1931); Philip M. Payne, Costs in Common Law Actions in the Federal Courts, 21 VA. L. Rev. 397, 430 1934. To be sure, the federal law on the subject had largely been stable since the Act of February 26, 1853, 10 Stat. 161, commonly referred to as the "Fee Bill of 1853." See id. at 404 et seq. 
contemplating that additional deposition or that extra set of interrogatories, attorneys need not worry about the fees charges other than the fees they themselves charge.

In the late 1980 s and early 1990 s, there were serious proposals for civil justice reform. Although attorney fee reform should be more easily accomplished than many other reforms, two of three studies avoided the topic altogether and accepted the status quo. The third made a timid suggestion of abolishing the rule in a small number of cases. The suggestion was met by vigorous criticism. ${ }^{88}$

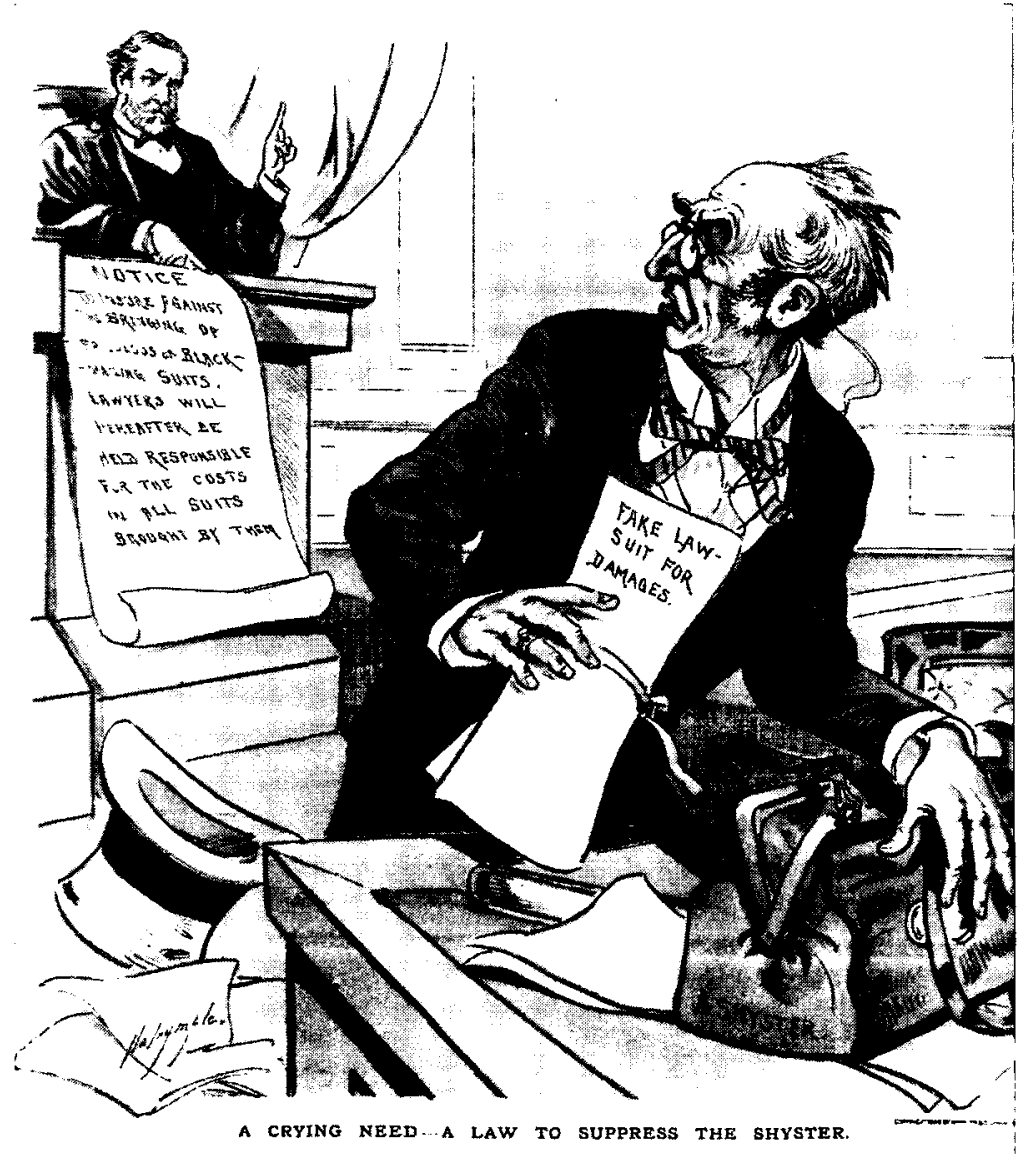

\section{A CRYING NEED-A LAW TO SUPPRESS THE SHYSTER 40 Puck No. 1169 (July 17, 1899) 89}

88. See Ernst C. Stiefel \& James R. Maxeiner, Civil Justice Reform in the United States-Opportunity for Learning from "Civilized" European Procedure Instead of Continued Isolation?, 42 AM. J. CoMp. L. 147, 154 (1994).

89. The judge's scroll reads: "NOTICE: TO INSURE AGAINST THE BRINGING OF FALSE OR BLACK-MAILING SUITS, LAWYERS WILL HEREAFTER BE HELD RESPONSIBLE FOR THE 
The one proposal for a loser-pay rule that achieved substantial political traction and significant institutional support was the Republican Party's 1995 "Contract with America" program. The program as it passed the House of Representatives included a loser pay plank. The proposal ran into opposition on all fronts: from bar associations, who feared for their fees, from consumer groups, who saw loser pays as a way to limit recoveries, and from business groups, who were concerned for the unexpected. ${ }^{90}$

Recently, in December 2008, the Manhattan Institute issued a proposal for a loser-pays rule. That proposal appears to be the first serious loser-pays proposal to address what ought to be a necessary part of any successful indemnity rule: limitation on the amount of attorneys' fees subject to reimbursement. While on its face, it allows for reimbursement, it limits reimbursable fees to thirty percent of the difference between the amount at trial and the non-prevailing party's last settlement offer. ${ }^{91}$ Whether it will go anywhere, remains to be seen. It is no surprise that the plaintiff's bar reacted with criticism. ${ }^{92}$

Readers may wonder why American proponents of loser-pay rules do not consider limiting how much losers must reimburse to levels proportionate to amounts in controversy. Surprisingly, such an idea is hardly discussed. Perhaps the reason is that such a rule would likely have consequences lawyers would not like to consider. If fees reimbursable fees are limited, clients are likely to pressure them not to do more than the fees allow. Worse still, from lawyers' perspective, clients are likely to expect their lawyers to take no more in fees than what they are legally entitled to recover.

In the end, a limit on reimbursement could lead to the discussion that is of greatest need: keeping total expenses, whether subject of indemnity or not, proportionate with the matter in controversy.

COSTS IN ALL SUITS BROUGHT BY THEM." The lawyer's writ reads: "FAKE LAW SUIT FOR DAMAGES." His bag is marked "A SHYSTER."

90. See Olson \& Bernstein, supra note 2; Thomas D. Rowe, Jr., Indemnity or Compensation? The Contract with America, Loser-Pays Attorney Fee Shifting, and a OneWay Alternative, 37 WASHBURN L.J. 317 (1998) (referring to the "high water mark" for fee shifting).

91. Greater Justice, Lower Costs, supra note 63, at 18.

92. See, e.g., Tami Kamin-Meyer, Surprise! Conservative think tank study again suggests that"loser-pays" is right for America, PLAINTIFF MAGazine 1 (March 2009) available at www.plaintiffmagazine.com. 
